\title{
NASTAVENÍ MĚNOVĚ-POLITICKÝCH SAZEB VE VZTAHU K ÚVĚROVÉ A EKONOMICKÉ AKTIVITĚ
}

\section{Bohuslav Č́žek}

\section{Klíčová slova:}

měnová politika, cílování inflace, úvěry, ekonomická aktivita

\section{Key words:}

monetary policy, inflation targeting, loans, economic aktivity

\begin{abstract}
Abstrakt
Článek pojednává o úrokových sazbách nastavených ČNB a o jejich vztahu k úvěrové a ekonomické aktivitě. Ukazuje na komplexnost ekonomického systému, kde jednoduché komparace hodnot spolu s metodou jednoduché korelace ${ }^{1}$ sledovaných veličin mohou dávat odlišné hodnoty oběma směry, ale ekonomické principy ${ }^{2}$ se nemění. Musíme vzít v úvahu např́klad faktory jako ekonomická stabilita, celková ekonomická výkonnost, důvěra a očekávání subjektů. Měnově-politické sazby nejsou totiž faktorem jediným, ale rozhodně mají určitou sílu ovlivnit úvěrování a investiční aktivitu ve směru, který je v souladu se základními ekonomickými zákony a nebyla nalezeny data, logika či souvislosti, které by tento fakt vyvrátily. Článek dochází mimo jiné k závěru, že česká měnová politika je poměrně systematická a rozhodně nemůžeme mluvit pouze o kanálu ,úrokové sazby - úvěry ekonomická aktivita“, ale vazby působí i v opačném směru, kde ČNB bezpochyby reflektuje při nastavování úrokových sazeb očekávanou ekonomickou aktivitu v rámci svého rozhodovacího procesu.
\end{abstract}

\begin{abstract}
This article deals with interest rates set up by the CNB and their relation to loan and economic activity. It shows complexity of economic systems where simple comparisons may give various numbers but principles stay the same. We have to take into account factors like economic stability, overall economic performance, sentiment and expectations. The monetary policy interest rates are not the only factor but definitely they have some power in the direction which is in line with basic economic laws and there are no data, logics, or nexuses denying this fact. The article comes to the conclusion that the Czech monetary policy is quite systematic and we cannot definitely talk only about the "interest rates - loans - economic activity" channel but it also works in an opposite direction, where the ČNB reflects economic activity in its decision making process when setting the interest rates.
\end{abstract}

\section{Úvod}

Jednou ze základních hospodářských politik je v souladu s literaturou i ekonomickou praxí politika měnová ${ }^{3}$, kde naplňování cílů v rámci měnové strategie centrální banky odráží skutečnost komplexity a propojenosti řady souvislostí a ekonomických faktorů. Článek se snaží na základě literární rešerše uvedené v Kapitole 1, ekonomických principů, empirických dat, pomocí metodologie logických dedukcí, pomocí hledání souvislostí a metody korelace vyvodit základní vazby a souvislosti nastavení měnově-politické sazby ve vztahu k úvěrové

\footnotetext{
${ }^{1}$ Statistické metody v ekonomii např́iklad viz Hindls et al (2007)

${ }^{2}$ Ekonomické principy a měnová politika např́íklad viz Walsh (2003) či Mankiw (1999)

${ }^{3}$ Např́iklad viz Mankiw (1999) či Kliková a Kotlán (2003)
} 
aktivitě a následně $\mathrm{k}$ investicím a ekonomické aktivitě. Vazby jsou prokazovány pomocí kvalitativní analýzy vývoje dat a metody jednoduché korelace. Záměrem není výpočet čistého př́spěvku či sestavení matematického vzorce daných kanálů, ale teoreticky i empiricky zhodnotit vypozorované a několikrát logicky, či analýzou potvrzené vazby jako je určitá systematičnost reakcí ČNB zohledňující očekávaný vývoj HDP v nastavení sazeb, vliv ostatních faktorů a možnost existence všech kombinací výsledných hodnot zkoumaných veličin při zachování fungování základních ekonomických principů či znatelnější vazba (zkoumaná jednoduchou korelací či srovnáním výsledných dat) v souladu s ekonomickými zákonitostmi mezi veličinami v obdobích větších makroekonomických stabilit, např́íklad v ČR v roce 2005. Detailnější výsledky jsou obsaženy v analytické kapitole se závěry.

\section{Teoretický rozbor}

Primárním cílem ČNB je cenová stabilita, konkrétně dle Zákona o ČNB: „hlavním cílem České národni banky je péče o cenovou stabilitu. Pokud tím není dotčen její hlavní cíl, Česká národni banka podporuje obecnou hospodárskou politiku vlády vedouci k udržitelnému hospodářskému růstu. Česká národní banka jedná v souladu se zásadou otevřeného tržního hospodářstvi.“" (Zákon č. 6/1993Sb., o České národní bance). Tento cíl se výrazněji neliší od principů ECB (např́klad ECB 2004), dle které je „celkově nezbytné, aby měnová politika udržovala ve střednědobém horizontu cenovou stabilitu, a tak zajistila pevné ukotvení inflačnich očekávání v souladu scílem... Takové ukotveni inflačnich očekávání je předpokladem k tomu, aby měnová politika mohla prispívat k hospodářskému růstu a tvorbě pracovních mist veurozóně.“ (ECB 2011, s. 5). Cesta k naplnění cílů je spojena s mnoha kanály transmise, obsahuje řadu souvislostí, provázaností a ekonomických veličin odrážejících působení domácích i zahraničních faktorů. Transmisní mechanismus např́íklad dle definice ČNB představuje „řetězec ekonomických vazeb, který umožňuje, aby změny $v$ nastavení měnověpolitických nástrojů vedly $k$ žádoucím změnám inflace“ (ČNB online).

Ze základních ekonomických principů (např́íklad Walsh (2003) či Mankiw (1999)) a empirie 4 lze pomocí logických metod vyvodit hlavní zákonitosti vztahu měnově-politických sazeb k úvěrové a ekonomické aktivitě. Kanálů transmise můžeme vydefinovat celou řadu dle šíře a zaměření zkoumané oblasti - lze nalézt např́klad kanály akciové, kanál úrokový, bankovní (úvěrový), nákladů na kapitál, kurzový, přijímání rizika, bohatství, čisté hodnoty, finančního akcelerátoru, spotřební, investiční, př́ijmový, očekávání či oznámení. Základní kanál představuje kanál agregátní poptávky, kde měnová politika ovlivní krátkodobou nominální úrokovou sazbu a tím následně dostupnost úvěrů. Dopad na agregátní poptávku má určité zpoždění a inflace je výsledným efektem komplexního vztahu agregátní poptávky a agregátní nabídky, kterou úroková sazba může také ovlivnit např́klad ve formě nákladů na kapitál. Dále může měnová politika svými kroky ovlivnit inflační očekávání, neboli očekávání vývoje všech cen, tedy i mezd, a tím inflaci samotnou. V otevřených ekonomikách, kterými evropské ekonomiky bezpochyby jsou, nelze opominout ani kanál směnného kurzu. Vzhledem k zaměření článku na vztah měnově-politických sazeb s úvěrovou a ekonomickou aktivitou se nyní podívejme blíže na související teoretické a empirické souvislosti.

Dopady na úvěrování jsou v evropském a českém prostředí spojeny na nabídkové straně zejména s bankovními institucemi. Vztah měnové politiky a bank popisují např́klad Maddaloni, Luis Peydró a Scopel (2008): "Kvůli nedokonalým informacím, neúplným smlouvám a nedokonalé konkurenci bank může měnová politika ovlivnit nabídku půjček bank.

\footnotetext{
${ }^{4}$ Viz uvedená literatura, analýza dále a dlouholeté zkoumání problematiky autorem
} 
Expanzivní měnová politika může zvýšit nabidku úvěrů bank přimo skrze bankovní výpůjční kanál nebo nepřimo zlepšením čistého bohatství př́jemců dluhů a tím snižení nákladư na půjčováni (balance sheet channel). Dále také nízké úrokové sazby mohou zvýšit chut' bank riskovat (risk taking channel). " (MADDALONI - PEYDRÓ - SCOPEL 2008, s. 2). Nutné je si uvědomit, že to, co formuje úvěrovou aktivitu, není jenom základní sazba peněžního trhu, kde navíc cenu úvěru nevyjadřuje pouze úroková sazba samotná, ale ,cenou úvěru je vektor podmínek " (LOWN - MORGAN 2006, s. 1577), a je zde i velmi důležitá strana poptávky, kdy např́iklad podle studií Kashyap a Stein (1997) může být korelace bankovních úvěrů a ekonomické aktivity řízena změnami v poptávce po bankovních úvěrech spíše než změnami v jejich nabídce. Berger a Bouwman (2010) přicházejí také s empirií odvozenými závěry, že „měnová politika je slabši během finančních krizí ně̌ v normálních časech... tvorba likvidity predcházi finančním krizím, a tak je klíčivou přičinnou proměnnou v predikci finanční krize“ (BERGER - BOUWMAN 2010, s. 24).

Empirické důkazy ukazují, že bankovní úvěry by měly být korelovány s mírami ekonomické aktivity. Podíváme-li se např́klad na čtvrtletní data pro Českou republiku a porovnáme-li meziroční vývoj úvěrů ${ }^{7} \mathrm{~s}$ meziročním vývojem reálného $\mathrm{HDP}^{8}$, tak v období od čtvrtého čtvrtletí 1997 až do 1 . čtvrtletí 2012 vychází jednoduchá korelace pozitivní ve výši 0,41 . Pokud ale období zkrátíme na období „bez krizí“ a podíváme se na roky 2000 až 2008, pak lze pozorovat výraznější korelaci vztahu ekonomické a úvěrové aktivity ve výši 0,676. Výpočet korelačního koeficientu je na základě uvedených dat pomocí nástroje Microsoft Office Excel 2007 plně v souladu s výpočtem jednoduchého korelačního koeficientu ${ }^{9}$ určujícího míru lineární závislosti dvou veličin ${ }^{10}$.

Následný celkový dopad změny měnově-politické sazby na ekonomickou aktivitu již neodráží pouze kanál úvěrový, ale změna nastavení sazeb ovlivní i faktory chování ekonomických subjektů a tím faktory výsledků ekonomiky jako jsou očekávání ekonomického vývoje, ochota utrácet a spořit, směnné kurzy či akciové trhy. Z pohledu zejména úvěrového kanálu lze celkově souhlasit s Kvapilovou a Sharlerem (2007), když shrnují, že „vliv měnové politiky na agregátni poptávku a inflaci závisí na stupni, ve kterém změny měnově-politických sazeb jsou preneseny do tržnich a maloobchodnich úrokových sazeb (KVAPIL - SCHARLER 2007, s. 19).

Mechanismy vztahu měnově-politických šoků a makroekonomických agregátů (HDP a inflace) jsou uplatňovány $\mathrm{v}$ makroekonomický modelech a potvrzovány empirickým testováním i logickými závěry ekonomických teorií, což potvrzuje např́íklad i Benkovskis et al. (2011), Claridá et al. (1998) či Hušek a Švarcová (2007). Empirické analýzy ECB (2010) ukazují, že v průměru trvá ve vyspělých průmyslových ekonomikách až jeden rok než se změna měnové politiky s největším efektem projeví na agregátní poptávku a produkci, a pak

\footnotetext{
${ }^{5} \mathrm{~V}$ důsledku existence asymetrie a nedokonalosti informací se cena neprojevuje pouze skrze nominální cenu úvěru, ale také skrze nastavení celého produktu - podmínky ručení, poplatky apod.

${ }^{6}$ Ve sledovaném období přestože uvolněná MP převládala v krizích, tak to neznamená, že je uvolněná vždy uvolněná byla v 83 \% krizových čtvrtletích z pohledu změny americké základní měnové politické sazby federal fund rate a v 58\% čtvrtletích z pohledu MP šoku, který definují jako změnu či opravu federal fund rate oproti očekáváné původně špatně nastavené sazbě

${ }^{7}$ Zdroj: ČNB, databáze ARAD, definováno jako úvěry obchodních bank - klientské, nefinančním podnikům, data za čtvrtletí, vlastní dopočet meziročního indexu

${ }^{8}$ Zdroj: data ČSU, národní účty, definováno jako: čtvrtletní HDP, reálný vývoj (ve stálých cenách :SOPR=100) meziroční index

${ }^{9}$ Počítaného jako poměr kovariance veličin a odmocniny ze součinu rozptylů

${ }^{10}$ Metodika výpočtu a význam např́íklad viz Hindls et al (2007)
} 
zhruba další rok pro plný efekt do inflace. Dále například Bank of England pomocí svého makroekonomického modelu (např́íklad George 1999) simuluje velikost a načasování těchto dopadů na HDP a inflaci a ukazuje, že jeden procentní bod neočekávaného zvýšení úrokové sazby trvající jeden rok ovlivní reálný HDP relativně rychle a největší pokles přichází zhruba za pět čtvrtletí ve výši cca 0,2 - 0,35 p.b., následně se začne HDP vracet do své původní rovnovážné úrovně (dle uvedené studie do 3 let). Naproti tomu inflace se v prvním roce mění pouze minimálně, prudce klesat začíná až ve druhém roce a maximálního dopadu dosahuje v devátém čtvrtletí ve výši $0,2-0,4$ p.b. Dlouhodobou reakci HDP na změnu měnověpolitické sazby formou šoku v USA zkoumal např́klad Uhlig (2005) za roky 1965-2003, kdy dochází k výsledkům, že po zvýšení federální úrokové sazby o 20 bp vykazuje zpočátku HDP často vývoj v souladu s většinou studií, neboli že dojde v určité míře ke snížení HDP. Dlouhodobě však je tato změna měnově-politické sazby schopna posunout reálný HDP na hodnoty $\mathrm{v}$ intervalu plus mínus $0,2 \%$, čímž se vliv změny nastavení měnově-politických sazeb vytrácí.

Podívejme se nyní na analýzu pro dané souvislosti pro Českou republiku. ČNB v rámci svého měnového režimu cílování inflace primárně nereaguje pouze na současné výsledky. Reaguje na ně samozřejmě ve smyslu změny předpokladů a zabudování změn do očekávaného vývoje. Dočasné krátkodobé výrazné změny mohou v dlouhém období být pro prognózy měnové politiky méně významné. Reaguje obecně na signály o budoucích výsledcích, kam bezpochyby současné výsledky patří. Současné výsledky a historická data dokonce budoucí výsledky pomáhají předvídat a do jisté míry je formují. Analýzou či zjednodušeným rozborem ekonomické situace, předstihových indikátorů ${ }^{11}$ a makroekonomických prognóz různých institucí ${ }^{12}$ tak velmi často můžeme očekávat (či odvozovat) možné reakce ČNB, nebo alespoň směr reakcí, samozřjmě v určitém intervalu. Měnová politika ČNB ekonomiku záměrně nešokuje. Navíc existují faktory, které měnová politika z rozhodování o nastavení měnově-politických sazeb v primární fázi vylučuje.

Přejděme nyní na základě výše uvedených souvislostí k cíli článku, kde následující analýza zkoumá pomocí srovnání vazeb mezi jednotlivými veličinami a pomocí metody korelace možné vazby nastavení hlavní měnově-politické sazby ČNB a úvěrové a následně i ekonomické aktivity. Vydefinujme nejprve předpoklady, které budou sloužit jako základ vyvození závěrů vycházejících z výše uvedených principů a na základě uvedených metod. Vymezení předpokladů dále přibližuje metodiku a upřesňuje zázemí pro zkoumání vztahů veličin v rámci transmise měnové politiky.

\section{Nastavení měnově-politických sazeb ve vztahu k úvěrové a ekonomické aktivitě - předpoklady, data, korelace a vztahy}

- Pro komparaci dat, analýzu funkčního vztahu a výpočet korelačního koeficientu autorem sestavena tabulka (Tabulka č. 1).

- Použity základní makroekonomické agregáty - pro úvěrovou aktivitu celkový objem úvěrů nefinančním podnikům (definovaný jako úvěry celkem v mil. Kč - sektor nefinančních podniků, zdroj data $\check{\mathrm{C} N B}$ ), pro ekonomickou aktivitu HDP ve stálých cenách (HDP,

\footnotetext{
${ }^{11}$ Podíl investic na HDP, objemy nových zakázek, konjunkturální průzkumy, indexy cen výrobců, počet stavebních povolení, vývoj ekonomiky hlavních obchodních partnerů, vývoj produktivity práce vs. vývoj mezd apod.

${ }^{12}$ Makroekonomické predikce zpracovává například ČNB, MFČR, Patria, LIBINST (Liberální institut), OECD, MMF, Česká bankovní asociace, Komerční banka a jiné instituce
} 
čtvrtletní data, stálé ceny v mil. Kč, zdroj Národní účty ČSU)a investice ve stálých cenách (vymezené jako čtvrtletní hodnota tvorby hrubého fixního kapitálu, stálé ceny v mil. Kč, zdroj Národní účty ČSU). Tyto veličiny jsou zkoumány ve vztahu k měnově-politické sazbě.

- Uvedené indexy v Tabulce č. 1 jsou pouze doplněním pro další zkoumání (zdroj indexy ve statistikách ČSU).

- Základní výchozí veličinou zkoumání je měnově-politická sazba, kterou v ČR představuje takzvaná 2T Repo sazba ČNB (hodnota ke konci čtvrtletí dle údajů ČNB).

- Použita metoda takzvané jednoduché korelace ${ }^{13}$.

- Použito kvalitativní porovnání funkčního vztahu vývoje veličin míry úrokové sazby a vývoje výše úvěrů, HDP a investic jako základních proměnných zkoumaného vztahu uvedeného v názvu a cíli práce (zkoumáno znaménko směrnice funkce/vztahu).

- Nejsou zohledněny jednorázové vlivy jako investiční pobídky a výrazné přílivy investic, hospodářská krize apod., které bezpochyby na výsledné zkoumané veličiny ve sledovaném období působily.

- Vybrané období zvoleno z důvodu dostupnosti kompatibilních relevantních dat a užívaných statistických metodik sledování vývoje veličin.

- V základní tabulce není uvažováno zpoždění, propočty pro zpožděné hodnoty provedeny bez zobrazení do tabulky.

- Čtvrtletní data - u ekonomické výkonnosti a výše investic očištěna o sezonní výkyvy.

- Není zvažováno očekávání ve smyslu, že část efektu očekávané změny měnově-politické sazby může působit již ve čtvrtletí před změnou sazeb, neboli vliv zabudování očekávání rozhodnutí centrální banky trhy před samotným oficiálním rozhodnutím Bankovní radou ČNB.

- Dopady změny základní měnově-politické sazby sledovány ve vztahu k reálným veličinám.

- Tabulka č. 1 explicitně v rámci komparace vývoje dat a metody jednoduché korelace nezohledňuje vzájemnou determinaci veličin, což není ani cílem. Výsledky nicméně umožňují částečně potvrdit otázku jak vzájemné propojenosti tak působení dalších faktorů.

Na základě výše uvedených předpokladů byla sestavena tabulka, která demonstruje vývoj jednotlivých veličin na čtvrtletních datech od roku 2000 do poloviny roku 2012. Dále na datech vyobrazuje v daném období funkční vztahy mezi vývojem jednotlivých veličin pomocí barevného vyznačení. V neposlední řadě byly spočítány jednoduché korelační koeficienty zkoumaných veličin jako poměr kovariance veličin (veličinou jsou časové řady hodnot sledované proměnné) a odmocniny ze součinu rozptylů.

\footnotetext{
${ }^{13}$ Veškeré takzvané jednoduché korelační koeficienty vypočteny autorem pomocí nástroje Microsoft Office Excel 2009, viz poznámka pod čarou 9 a 10
} 
Tabulka1: Analýza nastavení měnově-politických sazeb ve vztahu k úvěrové a ekonomické aktivitě - data, propočty a vztahy

\begin{tabular}{|c|c|c|c|c|c|c|c|}
\hline Období & $\begin{array}{c}2 \mathrm{~T} \text { Repo } \\
\text { sazba } \\
\text { ("2TR") }\end{array}$ & $\begin{array}{c}\text { Úvěry a } \\
\text { pohledávk } \\
\text { y za } \\
\text { klienty } \\
\text { celkem } \\
\text { ("Úvěry") }\end{array}$ & $\begin{array}{c}\text { Index } \\
\text { průmyslov } \\
\text { é } \\
\text { produkce } \\
\text { (bazické } \\
\text { indexy, } \\
\text { průměrné } \\
\text { čtvrtletí } \\
2005=100 \text { ) }\end{array}$ & $\begin{array}{c}\text { HDP } \\
\text { (stálé } \\
\text { ceny) } \\
\text { ("HDP") }\end{array}$ & $\begin{array}{l}\text { Meziroční } \\
\text { tempo } \\
\text { růstu } \\
\text { HDP } \\
\text { (stálé } \\
\text { ceny, } \\
\text { SOPR,se } \\
\text { zonně } \\
\text { očištěno) }\end{array}$ & $\begin{array}{l}\text { Investice } \\
\text { (THFK, } \\
\text { mil.Kč, stálé } \\
\text { ceny, } \\
\text { sezonně } \\
\text { očištěno) } \\
\text { ("Investice") }\end{array}$ & \begin{tabular}{|c} 
Investice \\
(meziročn \\
í reálný \\
růst)
\end{tabular} \\
\hline 31.3 .2000 & 5,25 & $\begin{array}{|ll|}583 \quad 194 \\
\end{array}$ & 72,4 & 549043 & 3,5 & 152802 & 103 \\
\hline 30.6 .2000 & 5,25 & 585929 & 75,7 & 557936 & 4,6 & 156140 & 104,7 \\
\hline 30.9 .2000 & 5,25 & 612836 & 74,5 & 565674 & 5,2 & 159431 & 108,7 \\
\hline 31.12 .2000 & 5,25 & 591030 & 84,1 & 569395 & 4,8 & 164258 & 110,2 \\
\hline 31.3.2001 & 5 & 570465 & $\mathbf{8 1 , 1}$ & 580794 & 4,4 & 169094 & 107,3 \\
\hline 30.6 .2001 & 5 & 567656 & 83,2 & 584579 & 3,4 & 169076 & 105 \\
\hline 30.9.2001 & 5,25 & 455542 & 78,2 & 587698 & 2,5 & 170911 & 103,9 \\
\hline 31.12.2001 & 4,75 & 423545 & 87,1 & 589443 & 2,1 & 172733 & 101,9 \\
\hline 31.3 .2002 & 4,25 & 406875 & 79,9 & 619054 & 1,9 & 178329 & 103,4 \\
\hline 30.6.2002 & 3,75 & 376237 & 84,3 & 623138 & 1,9 & 179854 & 104,3 \\
\hline 30.9 .2002 & 3 & 359798 & 83 & 627429 & 2 & 181128 & 103,9 \\
\hline 31.12.2002 & 2,75 & 344361 & 96,1 & 631839 & 2,4 & 182651 & 103,7 \\
\hline 31.3.2003 & 2,5 & 351061 & 83 & 657048 & 3,4 & 169742 & 97,2 \\
\hline 30.6 .2003 & 2,25 & $\begin{array}{|ll|}341654 \\
\end{array}$ & 86,1 & 662140 & 3,5 & 175849 & 99,8 \\
\hline 30.9.2003 & 2 & 342697 & 85,7 & 669747 & 4 & 181565 & 102,3 \\
\hline 31.12 .2003 & 2 & 342643 & 93,9 & 675658 & 4,2 & 184291 & 103 \\
\hline 31.3 .2004 & 2 & 346440 & 92,3 & 688407 & 3,8 & 177973 & 103,5 \\
\hline 30.6 .2004 & 2,25 & 354130 & 97,6 & 695853 & 4,2 & 190893 & 107,1 \\
\hline 30.9 .2004 & 2,5 & \begin{tabular}{|l|}
377884 \\
\end{tabular} & 92,8 & 707793 & 4,7 & 186360 & 101,3 \\
\hline 31.12 .2004 & 2,5 & 373849 & 102,3 & 719874 & 5,6 & 186061 & 99,6 \\
\hline 31.3.2005 & 2,25 & 390279 & 93,8 & 761116 & 6,3 & 190799 & 104,8 \\
\hline 30.6.2005 & 1,75 & 410807 & 101,7 & 775157 & 7,1 & 206462 & 105,7 \\
\hline 30.9 .2005 & 1,75 & 424887 & 96,7 & 787607 & 7 & 203867 & 106,9 \\
\hline 31.12.2005 & 2 & 432324 & 107,8 & 800927 & 7 & 203539 & 106,9 \\
\hline 31.3 .2006 & 2 & 448558 & 104,6 & 816050 & 7,6 & 206552 & 108,3 \\
\hline 30.6 .2006 & 2 & 473230 & 108,4 & 828028 & 7,2 & 212135 & 102,8 \\
\hline 30.9.2006 & 2,5 & 497552 & 103,6 & 842194 & 7,3 & 210534 & 103,3 \\
\hline 31.12 .2006 & 2,5 & 516603 & 116,6 & 853076 & 6,9 & 222668 & 109,5 \\
\hline 31.3 .2007 & 2,5 & 527516 & 119 & 877937 & 7 & 247112 & 118,4 \\
\hline 30.6.2007 & 2,75 & 559085 & 120 & 876056 & 5,2 & 241911 & 112,9 \\
\hline 30.9 .2007 & 3,25 & 601059 & 113,5 & 890877 & 5,2 & 237956 & 111,9 \\
\hline 31.12.2007 & 3,5 & 616633 & 126,8 & 904123 & 5,4 & 247674 & 110,1 \\
\hline 31.3.2008 & 3,75 & 634892 & 121,5 & 939023 & 3,5 & 275175 & 109,6 \\
\hline 30.6 .2008 & 3,75 & 677260 & 124,7 & 948813 & 4,8 & 263764 & 107,3 \\
\hline 30.9 .2008 & 3,5 & 701564 & 114,4 & 950129 & 3,2 & 253727 & 104,9 \\
\hline 31.12.2008 & 2,25 & 692189 & 110,1 & 934967 & $\mathbf{0 , 1}$ & 237104 & 94,2 \\
\hline 31.3.2009 & 1,75 & 6881730 & 98,4 & 921569 & $-3,7$ & 231609 & 84,1 \\
\hline 30.6.2009 & 1,5 & 674670 & 101 & 911412 & $-5,8$ & 228730 & 86,6 \\
\hline 30.9.2009 & 1,25 & 667004 & 99,3 & 915002 & $-5,5$ & 227321 & 89,5 \\
\hline 31.12.2009 & 1 & 636069 & 107,8 & 923224 & $-3,1$ & 225673 & 95,1 \\
\hline 31.3 .2010 & 1 & 633605 & 105,2 & 948278 & 0,9 & 219060 & 93,1 \\
\hline 30.6.2010 & 0,75 & 629829 & 112,6 & 957442 & 3 & 229911 & 98,9 \\
\hline 30.9 .2010 & 0,75 & 644111 & 109,9 & 963947 & 3,3 & 240349 & 104,1 \\
\hline 31.12 .2010 & 0,75 & 636033 & 120,6 & 969540 & 3 & 238646 & 104,1 \\
\hline 31.3 .2011 & 0,75 & 654877 & 117,9 & 957634 & 2,8 & 213460 & 98 \\
\hline 30.6 .2011 & 0,75 & 670829 & 122,4 & 960196 & 2,1 & 232120 & 101,6 \\
\hline 30.9 .2011 & 0,75 & 677603 & 113,5 & 959757 & 1,3 & 232668 & 97,4 \\
\hline 31.12 .2011 & 0,75 & 669369 & 123,5 & 958091 & 0,6 & 235863 & 99,4 \\
\hline 31.3 .2012 & 0,75 & 677825 & 121,3 & 945368 & $-0,5$ & 216573 & 101,6 \\
\hline 30.6.2012 & 0,5 & 679623 & 121,3 & 943101 & -1 & 231796 & 100 \\
\hline & 2TR & $-0,179$ & & $-0,735$ & & $-0,52$ & \\
\hline & úvěry & 1 & & 0,657 & & 0,621 & \\
\hline & HDP & 0,657 & & 1 & & 0,93 & \\
\hline Korelace & Investice & 0,621 & & 0,93 & & 1 & \\
\hline
\end{tabular}

Zdroj: vlastní výpočty, úpravy. Podkladová data na základě dat ČNB a ČSU 


\section{Nastavení měnově-politických sazeb ve vztahu $k$ úvěrové a ekonomické aktivitě - závěry}

S cílem větší přehlednosti a systematičnosti jsou autorem vyvozené závěry na základě v článku uvedených principů, studií a výše uvedených metod strukturovány následně do jednotlivých bodů.

- Tabulka č. 1 ukazuje vazby mezi měnově politickými sazbami a úvěry a ekonomickou aktivitou vyjádřeno investiční aktivitou a ekonomickou výkonností celkově (měřeno reálným HDP).

- Pokud reálné proměnné ve sledované časové řadě zpozdíme o 1 čtvrtletí oproti vývoji hlavní měnově-politické sazby (získáme datovou řadu končící v 1. čtvrtletí 2012), jednoduché korelační koeficienty se výrazně neliší, u investic a HDP je dokonce nepatrně (v ř́a setin) slabšr ${ }^{14}$.

- Pokud reálné proměnné zpozdíme o 1 rok oproti vývoji hlavní měnově-politické sazby (získáme datovou řadu končící v 2. čtvrtletí 2011) v souladu s uvedenými empiriemi o zhruba ročním zpoždění na HDP, pak jednoduché korelační koeficienty jsou sice mírně vyšší, ale u investic a HDP se výrazněji nelišsi ${ }^{15}$. Tento výsledek dává důkaz jedné ze souvislostí systematičnosti mechanismu cílování inflace ČNB. Systematičnost reakcí ČNB na očekávaný vývoj veličin ekonomické výkonnosti je jedním ze závěrů článku, kde ČNB při nastavování sazeb reaguje na očekávaný vývoj HDP a nastavení sazeb je reakcí na komplexní analýzu souvisejících faktorů determinujících cenovou hladinu, včetně právě vývoje HDP.

- Vidíme, že vazba mezi úrokovými sazbami a úvěry či investicemi je při jednoduchém srovnání nalezena ve všech kombinacích, tedy při snížení jak roste (zelená barva) tak klesá (modrá barva) a při růstu také v určitých obdobích roste (žlutá) a v určitých klesá (oranžová). To opět indikuje a dokazuje působení a vliv ostatních faktorů, spolu s tím, že měnová politika ČNB je systematická ve smyslu reakcí na očekávaný reálný vývoj a změna sazeb je tedy v souladu s očekávaným vývojem samotných reálných veličin. V souladu s tímto tvrzením je i výsledná korelace HDP a 2TRepo sazby.

- Matice korelací ve svých finálních znaméncích potvrzuje ekonomické zákonitosti, nicméně důležitý je i detailní pohled, který vzhledem k předchozímu uvedenému závěru, závěry o síle pro tyto korelace oslabuje.

- Velmi silná korelace je mezi investicemi a HDP, což je logické z několika důvodů. Mezi hlavní důvody patř́ to, že investice jsou součástí HDP) v ČR dle dat Národních účtů zveřejňovaných ČSÚ a EUROSTATEM se podíl tvorby hrubého fixního kapitálu pohybuje v posledních letech kolem $25 \%$ (V roce 2011 to bylo $24 \%$, měreno jako podíl Tvorby

\footnotetext{
${ }^{14}$ Vzhledem $\mathrm{k}$ omezenému rozsahu není tabulka součástí článku, jednoduché korelační koeficienty v př́ípadě zpožděných proměnných vycházejí: 2TReposazba ČNB a úvěry -0,206, 2TReposazba ČNB a HDP -0,729, 2TReposazba ČNB a investice $-0,506$

${ }^{15}$ Vzhledem k omezenému rozsahu není tabulka součástí článku, jednoduché korelační koeficienty v př́ípadě zpožděných proměnných (t-4) vycházejí: 2TReposazba ČNB a úvěry -0,389, 2TReposazba ČNB a HDP -0,742, 2TReposazba ČNB a investice - 0,563
} 
hrubého fixního kapitálu na HDP v běžných cenách $\left.{ }^{16}\right)$. Dále investiční aktivita odráží výsledky a možnosti podniků, pokud ekonomická aktivita klesá, klesá firmám v rámci investiční analýzy stránka výnosová. Nižší očekávaná výnosnost ovlivněná výsledky ekonomiky logicky vede k menšímu počtu výnosných a tím realizovaných investic. A naopak.

- Nyní se podívejme na vztah měnově-politické sazby bez zohlednění výše řečené vazby chování centrální banky při nastavování sazeb. V tomto př́padě, oproti klasickým ekonomickým vazbám mezi jednotlivými veličinami je vztah vyjádřený barvou modrou a žlutou. Vzhledem k zákonitostem potvrzeným v celé této práci můžeme i nyní potvrdit, že v letech 2006-2008, kdy ekonomika rostla a očekávání ekonomických subjektů byla pozitivní, i přes snížení sazby nedošlo k poklesu růstu úvěrů, investic a HDP. Centrální banka jednala v rámci svého inflačního cíle a postupně, nikoliv jednorázově výrazně, zvyšovala základní sazbu s cílem zamezit větším inflačním tlakům. Optimismus a výsledky ekonomiky tak byly impulsem pro centrální banku, jak mírně zpomalit tempa růstu, tím dosáhnout menšího přehřívání ekonomiky (ve smyslu ekonomického pojetí vyjádřeného jako kladný output gap) a tím větší přiblížení se inflačnímu cíli. Naopak konec roku 2008 a rok 2009 bylo obdobím výrazné nestability, nejistých očekávání, ekonomického poklesu, který byl do české ekonomiky přiveden skrze exportní kanál. Nejednalo se primárně o finanční, ale o hospodářskou krizi vyvolanou poklesem zahraniční poptávky. Pokles poptávky představuje protiinflační faktor umožňující centrální bance uvolnit měnovou politiku v rámci svého cíle, samozřejmě se zohledním ostatních pro a protiinflačních faktorů. Navíc se ukazuje, že období výraznějších nestabilit a období, kdy skutečný HDP se výrazně liší od svého potenciálu - at' už je blízko svých maxim či minim v rámci daného hospodářského cyklu -, jsou období, která sama o sobě ovlivňují ekonomické výsledky. Nastavení měnově-politických sazeb tak neplyne z politického rozhodnutí centrální banky, ale je reaktivní v rámci plnění cílu centrální banky. Oba př́ílady ukazují, že pokud centrální banka reaguje, tak se nejedná o vztah ve směru od rozhodnutí měnové politiky k vývoji sazeb. Ale o vazbu obousměrnou, centrální banka reaguje na ekonomický vývoj ovlivňující očekávání a na očekávaný ekonomický vývoj, zároveň však její rozhodnutí má sílu tento vývoj ovlivnit. Ale opět je pouze jedním z faktorů, a tak pokud ostatní faktory jsou výraznější, tak její změna nastavení sazeb pouze zmírňuje vývoj, který by nastal $\mathrm{v}$ př́ípadě, že by centrální banka změnu neprovedla, jak ukazují výše zmíněné př́iklady. Článek ukazuje, že měnová politika a změna nastavení sazeb ovlivňuje ostatní úrokové sazby, úvěrovou aktivitu, investice a ekonomiku, aniž to musí být na první pohled vidět a nástroje se mohou zdát $\mathrm{v}$ konečném důsledku jako neúčinné $\mathrm{v}$ dobách nízkých sazeb a ekonomické krize či stagnace vlivem negativních očekávání a neochoty soukromých subjektů spotřebovávat a investovat. V těchto prrípadech se efekt přelévá v mnohem menší míře z finančních trhů do trhů reálných a centrální banka pomáhá nastavením sazeb zejména stabilizaci finančních trhů. Vývoj zahraničních trhů či politická nestabilita, které však centrální banka nedokáže ovlivnit, mohou ale tento faktor převážit, a tak konečný efekt nemusí být se znaménkem klasického vztahu čistě vazby nastavení měnově-politické sazby a úvěry a investice.

- Možnost subjekti̊ na trhu analyzovat a odhadovat chování měnové politiky ČNB lze pozorovat v očekáváních finančních trhů, kde akciové, peněžní a devizové trhy v řadě př́ípadů zabudovávají očekávané změny nastavení měnové politiky do svých „cen“ do

\footnotetext{
${ }^{16}$ Vlastní propočet na základě dat národních účtů (ČSU) - čtvrtletní národní účty v běžných cenách, dle dat k 110.2012 dostupných na www.czso.cz
} 
určité míry s předstihem. Impulsem mohou být jak očekávání finančních analytiků, „naznačující“ výroky členů bankovní rady tak makroekonomické prognózy ukazující na odchylku očekávané inflace od inflačního cíle na měnově-politickém horizontu spolu $\mathrm{s}$ ostatními makroekonomickými souvislostmi. To platí zejména $\mathrm{v}$ dlouhodobě stabilních ekonomických podmínkách a jednotně signalizujících makroekonomických prognózách. Obzvláště v dobách „zvýšených nejistot“ a větší recesní mezery či „přehnaných očekávání“ a „rychlém růstu“ pak mohou na chování ekonomických subjektů působit výrazně i jiné faktory reálných podmínek ekonomiky a jimi může být finálně pozorovaný efekt změny měnově-politických sazeb na úvěry a investice převážen.

\section{Závěr}

Práce ukazuje, že měnová politika reaguje na cíl inflace. Hlavní závěry jsou shrnuty v bodech kapitole „3. Nastavení měnově-politických sazeb ve vztahu k úvěrové a ekonomické aktivitě - závěry“. Politika ČNB dle autora nezamýšlí v rámci nastavení úrokových sazeb narušení trendů výsledků ekonomických veličin a ve svém nastavení úrokových sazeb zohledňuje právě očekávaný vývoj veličin ekonomické výkonnosti samotných. Článek indikuje otevření diskuse k vyvrácení či posunutí stávajícího systému prognózních modelů. Doposud totiž nebyly nalezeny funkční mechanismy, které by spolehlivě indikovaly, na aktuálních datových souborech, průchodnost jednoznačných opatření řídícího měnového orgánu. Doporučení pro podnikatele je sledovat v krátkém období inflační prognózy a klíčové faktory ekonomiky, které se ho př́mo dotýkají. Z oblasti měnové politiky musí vnímat komentáře ekonomů o nekonvenčních krocích a změnách, které by dosavadní politiku českého systému politiky mohly narušit nebo vyvolat skrytá rizika. V dlouhém období může pro své podnikatelské plány využít inflační cíl, protože zůstane-li měnová politika transparentní a důvěryhodná, tak dlouhodobě v průměru bude provádět kroky, které zajistí plnění cíle trendově, s určitými oscilacemi, které jsou převážně šokového charakteru, a tak je nelze přesně dlouho dopředu předvídat. V této souvislosti by měl podnikatel sledovat oblasti, které se týkají výjimek z plnění inflačního cíle a faktory, které mohou nastavený cíl zejména krátkodobě výrazně ovlivnit, jako jsou daňové šoky, energetické a potravinové šoky a vývoj světové ekonomiky. Podnikatele, na rozdíl od centrálních bankéřù, se v praxi totiž zajímají především o krátké období vývoje cen a jejich vnímání a cíle nemusí být shodné s cíli centrálních bankeerrù, kteří vnímají ekonomiku z makroekonomického pohledu a problémy konkrétních společností tak mohou představovat např́ílad situaci fungování tržních sil či jen dílčí faktor v komplexu faktorů rozhodování centrálních bank.

\section{Literatura:}

[1] BERGER, A. N. - BOUWMAN, C. H.S. (2010): Bank liquidity creation, monetary policy, and financial crises [online]. Wharton Financial Institutions Center - working paper. Dostupné na: $<$ http://web.mit.edu/cbouwman/www/downloads/BergerBouwmanFinCrisesMonPolicyA ndBankLiqCreation.pdf $>$.

[2] BENKOVSKIS, K. ET AL. (2011): The Transmission of Euro Area Monetary Shocks to the Czech Republic, Poland and Hungary: Evidence from a FAVAR Model. Focus on European Economic Integration. Oesterreichische Nationalbank, 3/2011: 8-36.

[3] CLARIDA R. ET AL.(1998): Monetary policy rules in practice, some international evidence. European economic review, 42: 1033-1067.

[4] ČNB: Slovník pojmů [online]. Praha: ČNB, C 2003-2012 [cit. 2012-10-01]. Dostupné na: <http://www.cnb.cz/cs/obecne/slovnik/t.html>. 
[5] ČNB: Statistický systém ARAD [online]. Praha: ČNB, C Česká národní banka, 2003-2009 [cit. 2012-09-01]. Dostupné na: <http://www.cnb.cz/docs/ARADY/HTML/index.htm.>.

[6] ČSÚ: Statistiky [online]. Praha: ČSÚ, C Český statistický úřad, 2012 [cit. 2012-09-01]. Dostupné na: <http://www.czso.cz/csu/redakce.nsf/i/statistiky>.

[7] ECB (2004): The implementation of monetary policy in the Euro area. ECB, Frankfurt nad Mohanem. ISSN 1725-714X.

[8] ECB (2010): Monetary policy transmission mechanism in the Euro area, a decade after the introduction of the Euro. ECB Monthly Bulletin, 5/2010.

[9] ECB (2011): ECB Monthly Bulletin, 12/2011. ISSN 1725-2822.

[10] GEORGE, E. ET AL. (1999): The transmission mechanism of monetary policy [online]. Bank of England (C) 2012 [cit. 2012-8-24]. Bank of England - official paper. Dostupné na $<$ http://www.bankofengland.co.uk>.

[11] HINDLS, R. ET AL. (2007): Statistika pro ekonomy. Professional Publishing, Praha. ISBN 80-864419-99-1.

[12]HUŠEK,R. - ك̌VARCOVÁ, R.(2007): Modifikace IS-MP-IA modelu pro českou ekonomiku. Acta Oeconomica Pragensia, 15/1.

[13] KASHYAP, A. K. - STEIN, J. C. (1997): The role of banks in monetary policy. A survey with implications for the European monetary policy." Economic Perspectives, 8/1997: 218.

[14]KLIKOVÁ, CH. - KOTLÁN, I. (2003): Hospodářská politika. Sokrates, Ostrava. ISBN 80-86572-04-8.

[15] KVAPIL, C. - SCHARLER, J. (2007): Interest rate pass - through, monetary policy rules and macroeconomic stability. Oestrerreichische Nationalbank working paper, 118.

[16]LOWN, C. - MORGAN, D. P. (2006): The Credit Cycle and the Business Cycle: New Findings Using the Loan Officer Opinion surfy. Journal of Money. Credit, and Banking, $38 / 6$.

[17] MADDALONI, A. - LUIS PEYDRÓ, CH. - SCOPEL, S. (2008): Does Monetary Policy Affect bank credit standards?" Centre for economic policy research - The CEPR/ESI 12th Annual Conference on 'The Evolving Financial System and the Transmission Mechanism of Monetary Policy' 2008.

[18] MANKIW, G. N. (1999): Zásady ekonomie. Grada Publishing, Praha. ISBN 80-7169891-1.

[19] UHLIG, H. (2005): What are the effects of monetary policy on output? Results from an agnostic identification procedure. Journal of Monetary Economics, 52(2): 381-419.

[20] WALSH, C. E. (2003): Monetary Theory and Policy. Massachusetts Institute of Technology, Massachusetts. ISBN 0-262-23231-6.

[21]ZÁKON Č. 6/1993 o České národní bance v aktuálním znění 2011.

\section{JEL E42, E52}

\section{Ing. Bohuslav Čížek}

Doktorand Katedra ekonomických teorií

Provozně ekonomická fakulta

Česká zemědělská univerzita v Praze

Kamýcká 129, 16500 Praha - Suchdol

Tel.: 728424537

slavek.cizek@seznam.cz 